\title{
ANALISIS MENULIS UNSUR SERAPAN OLEH MAHASISWA PGSD SEMESTER IV KELAS II
}

\author{
Adelina Ginting \\ Surel: adelinaginting57@gmail.com
}

\begin{abstract}
This study aims to describe the ability of students in writing the element of absorption with the right (good and right). This research was conducted on PGSD student of Semester IV Class II as research subject, the number of students of PGSD Semester IV class II is 29 people. The research was conducted by giving a questionnaire as a source of what will be analyzed. Questionnaires to be done by students only write B (true) and $S$ (wrong). Based on the results of the survey, $48.27 \%$ (14 students) were categorized good, $24.13 \%$ (7 students) were sufficient kateogri, and $27.58 \%$ (8 students) were categorized as unfavorable.
\end{abstract}

Keywords: absorption element, foreign language, and Indonesian language.

\begin{abstract}
ABSTRAK
Penelitian ini betujuan untuk mendeskripsikan kemampuan mahasiswa dalam menulis unsur serapan dengan tepat (baik dan benar). Penelitian ini dilakukan pada mahasiswa PGSD Semester IV pada Kelas II yang dimana sebagai subjek penelitian, yaitu jumlah mahasiswa PGSD Semester IV pada kelas II adalah 29 orang. Penelitian dilakukan dengan memberi angket sebagai sumber dari yang akan dianalisis. Angket yang harus dikerjakan mahasiswa hanya menulis B (benar) dan S (salah). Berdasarkan hasil penelitian dari hasil angket yang dikumpulkan ternyata 48,27\% (14 orang) mahasiswa tergolong kategori baik, 24,13\% (7 orang) mahasiswa tergolong kateogri cukup, dan 27,58\% (8 orang) mahasiswa tergolong kategori kurang baik.
\end{abstract}

Kata Kunci: unsur serapan, bahasa asing, dan bahasa Indonesia.

\section{PENDAHULUAN}

Kata serapan lumrah terjadi antarbahasa. Proses serap-menyerap kata terjadi setiap kali ada kontak bahasa yang bersifat terbuka/mudah menerima pengaruh sehingga dalam kontak bahasa proses serapmenyerap unsur asing akan terjadi. Hal ini bisa dikarenakan adanya kebutuhan dan kemampuan seseorang yang kurang memahami bahasa sendiri. Dalam proses penyerapan bahasa, pasti akan timbul perubahan-perubahan. Sebab, tidak ada proses penyerapan yang terjadi secara utuh. Proses penyerapan terjadi dengan beberapa penyesuaian, baik dalam ejaan antarbahasa maupun ucapan.

Seperti yang kita ketahui, bahasa Indonesia tidak hanya terdiri dari bahasa murni asli inonesia saja. 
Dalam hal kosakata, bahasa Indonesia telah banyak menyerap unsur-unsur asing. Beberapa kosakata bahasa Indonesia juga dipengaruhi oleh bahasa asing, seperti bahasa Belanda, bahasa Arab, bahasaa Inggris dan bahasa Sanskerta. Unsur-unsur bahasa asing ini masuk ke Indonesia ketika bangsa Indonesia mengalami kontak budaya dengan bangsa asing. Unsur-unsur asing telah menambah sejumlah besar kata ke dalam bahasa Indonesia. Dengan adanya perkembangan bahasa ini, maka muncullah masalah-masalah kebahasaan. Misalnya, adanya kosakata yang diserap secara utuh dan dengan penyesuaianpenyesuaian, yang ternyata tidak lepas dari permasalahan analogi dan anomali bahasa.

Berdasarkan taraf integrasinya, unsur pinjaman dalam bahasa Indonesia dapa dibagi atas dua golongan besar yaitu:

Pertama, unsur pinjaman yang belum sepenuhnya terserap ke dalam bahasa Indonesia, seperti reshuffle, shuttle cock, long march. Unsur-unsur ini dipakai dalam konteks bahasa Indonesia, tetapi pengucapannya masih mengikuti cara asing.

Kedua, unsur pinjaman dan penulisannya disesuaikan dengan kaidah bahasa Indonesia. Dalam hal ini diusahakan agar ejaannya hanya diubah seperlunya sehingga bentuk Indonesianya masih dapat dibandingkan dengan bentuk asalnya. Misalnya saja central menjadi sentral, accomodation menjadi akomodasi, rhythm menjadi ritme, dan scenography menjadi senografi. Selain kata-kata di atas, tentunya masih banyak perbendahaaraan kata lain yang harus disesuaikan dengan EYD. Meski telah ada dan banyak buku yang diterbitkan mengenai bagaiamana penggunaan unsur serapan yang baik dan benar, akan tetapi masih sangat banyak mahasiswa yang tidak paham bagaiamana penggunaan dan penulisan unsur serapan yang benar. Untuk itu dilakukan penelitian mengenai penulisan unsur serapan oleh mahasiswa PGSD semester IV kelas II Universitas Katolik Santo Thomas Sumatera Utara.

Pada bagian ini, sebelum peneliti memaparkan mengenai menulis unsur serapan, terlebih dahulu peneliti memaparkan kemampuan atau sering disebut sebagai kompetensi dan pengertian menulis. Pada dasarnya kemampuan atau kompetensi diartikan sebagai suatu kecakapan yang dimiliki seseorang dalam melakukan suatu hal. Sementara itu, Tarigan (1993:21) menyatakan, menulis adalah menurunkan atau melukiskan lambang-lambang grafik yang mengambarkan suatu bahasa yang diapahami oleh seseorang, sehingga orang lain dapat membaca lambanglambang grafik tersebut kalau mereka memahami bahasa dan gambaran grafik tersebut.

Suparno (dalam Saddhono 2014:151) menyatakan, menulis 
merupakan kegiatan penyampaian pesan (komunikasi) dengan menggunakan bahasa tulis sebagai alat medianya. Sedangkan Dalman (2014:3) menyatakan, menulis merupakan suatu kegiatan komunikasi berupa penyampaian pesan (informasi) seacara tertulis kepada pihak lain dengan menggunakan bahasa tulis sebagai alat atau medianya. Berdasarkan uraian di atas, dapat disimpulkan bahwa menulis merupakan kegiatan penyampaian pesan secara tertulis menggunakan bahasa berupa lambang-lambang grafik sebagai medianya serta dapat dipahami oleh orang lain (pembaca).

Menurut Gebhardt dan Dawn Rodrigues (1989: 1) writing is one of the most important thing you do in college. Menulis merupakan salah satu hal paling penting yang kamu lakukan di sekolah. Kemapuan menulis yang baik memegan peranan yang penting dalam kesuksesan, baik itu menulis laporam proposal atau tugas di sekolah. Pengertian menulis diungkapkan juga oleh Barli Bram (2002: 7) in principle, to write means to try to produce or reproduce written message. Barli Bram mengartikan menulis sebagai suatu usaha untuk membauat atau mereka ulang tulisan yang sudah ada.

Dalam Kamu Umum Bahasa Indonesia, unsur serapan diartikan sebagai berikut: unsur adalah bahan asal, zat asal, bagian yang terpenting dalam suatu hal, sedangkan serapan adalah pemasukan ke dalam, penyerapan masuk ke dalam lubang- lubang kecil (Poerwadarminta, 1985: 130 dan 425). Menurut Samsuri (1987: 50) serapan dalah "pungutan". Sedangkan Kridalksana (1985: 8) memahami kata serapan adalah "pinjaman" yaitu bunyi, fonem, unsur gramatikal atau unsur leksikal yang diambil dari bahasa lain. Kata serpan adalah kata yang diesrap dari berbagai bahasa lain, baik dari bahasa daerah maupun dari bahasa asing, yang diguanakan dalam bahasa Indonesia yang cara penulisannya mengalami perubahan ataupun tidak mengalami perubahan.

Kata serapan digunakan oleh

Kridalaksana (1988), beliau menyebutkannya sebagai loan words atau kata-kata pinjaman. Istilahistliah tersebut digunakan untuk menyebut kosakata asli. Kosakata serapan merupakan kosakata yang diambil atau diserap dari satu bahasa donor dengan penyesuaian kaidah yang ada dalam bahasa penyerap.

Dari beberapa pendapat di atas dapat ditarik suatu simpulan bahwa unsur serapan dalah unsur dari suatu bahasa (asal bahasa) yang masuk dan menjadi bagian dalam bahasa lain (bahasa penerima) yang kemudian oleh penuturnya diapaki sebagaimana layaknya bahasa sendiri.

Proses penyerapan bahasa asing ke dalam bahasa Inodnesia dapat dipertimbangkan jika salah satu syarat di bawah ini terpenuhi yaitu:

a. Istilah serapan yang dipilih cocok konotasinya. 
b. Istilah yang dipilih lebih singkat dibandingkan dengan terjamahan Indonesianya

c. Istilah serapan yang dipilih dapat mempermudah tercapainya kesepakatan jika istilah Indonesia terlalu banyak sinonimnya.

Kata serapan masuk ke dalam bahasa Indonesi dengan tiga cara:

a. Adopsi

Pemakai bahasa mengambil bentuk dan makna kata asing itu secara keselurhan. Contoh: supermarket, plaza, mall

b. Adaptasi

Pemakai bahasa hanya mengambil makna kata asing itu, sedangkan ejaan atau penulisannya yang disesuaikan dengan ejaan bacaan bahasa Indonesia. Contoh: "Pluralization" menjadi "pluralisasi"

c. Penerjemahan

Pemakai bahasa mengambil konsep yang terkandung dalam bahasa asing itu, lalu kata tersebut dicari padanannya dalam bahasa Indonesia. Contohnya: "Try out" menjadi "ujicoba".

Dengan berpedoman pada rumusan masalah sebagaimana telah dikemukakan, selanjutnya penelitian ini bertujuan untuk :

a. Mengetahui kemampuan mahasiswa PGSD Semester IV Kelas II UNIKA St. Thomas menulis unsur serapan

b. Mengetahui pemahaman mahasiswa PGSD Semester IV Kelas II UNIKA St. Thomaskriteria penulisan unsur serapan sesuai dengan EYD c. Mengetahui manfaat mempelajari unsur searapan bagi mahasiswa PGSD Semester IV Kelas II UNIKA St. Thomas

\section{METODE PENELITIAN}

Dalam menyusun suatu karya tulis lebih-lebih yaqng bersifat ilmiah sudah barang tentu harus digunakan suatu metode yang baik, karena metode merupakan cara kerja untuk dapat memahami objek yang menjadi sasaran ilmu yang bersangkutan (Kuncaraningrat 1977:16) dengan metode yang tetpat dapat memecahkan masalah dengan baik.

Menurut Nazir (1988), metode deskriptif merupakan suatu metode dalam meneliti status sekelompok manusia, suatu objek, suatu set kondisi, suatu sistem pemikiran ataupun suatu kelas peristiwa pada masa sekarang. Tujuan dari penelitian deskriptif ini adalah untuk membuat deskripsi, gambaran, atau lukisan secara sistematis, faktual dan akurat mengenai fakta-fakta, sifat-sifat serta hubungan antarfenomena yang diselidiki. Sedangkan menurut Sugiyono (2005) menyatakan bahwa metode deskriptif adalah suatu metode yang digunakan untuk menggambarkan atau menganalisis suatu hasil penelitian tetapi tidak digunakan untuk membuat kesimpulan yang lebih luas. Menurut Whitney (1960), metode deskriptif adalah pencarian fakta dengan interpretasi yang tepat. 
Metode penelitian kualitatif adalah metode untuk menyelidiki obyek yang tidak dapat diukur dengan angka-angka ataupun ukuran lain yang bersifat eksak. Penelitian kualitatif juga bisa diartikan sebagai riset yang bersifat deskriptif dan cenderung menggunakan analisis dengan pendekatan induktif.

Dari metode-metode tersebut di atas yang paling tepat diterapkan untuk penelitian penulisan unsur serapan oleh mahasiswa PGSD Semester IV Kelas II adalah metode deskriptif kualitatif. Penerapan metode tersebut dalam penelitian ini menempuh langkah-langkah sebagai berikut:

a. Menginventarisasi data melalui angket

b. Deskripsi data

c. Klasifikasi data

Sutopo (2002:36) teknik cuplikan penelitian kualitatif cenderung bersifat purposive karena dipandang lebih mampu menangkap kelengkapan dan kedalaman data. Arikunto (2006:139) Sampel bertujuan atau purposive sample dilakukan dengan cara mengambil subjek bukan didasarkan atas strata, random atatu daerah tapi didasarkan atas ada tujuan tertentu. Teknik ini biasanya dilakukan karena beberapa pertimbangan misalnya, alasan keterbatasan waktu, tenaga, dan dana sehingga tidak dapat mengambil sample yang besar dan jauh.

Teknik penelitian dilakukan dalam rangka mengumpulkan bahanbahan penelitian ini ditempuh melalui dua tahap yaitu, tahap

pertama, studi lapangan, tahap kedua, studi pustaka. Studi lapangan untuk mendapatkan penulisan unsur serapan oleh mahasiswa PGSD Semester IV Kelas II dengan mengisi angket yang disediakan oleh peneliti. Studi pustaka dilakukan untuk mendapatkan sumber data atau kriteria serta kaidah-kaidah yang berlaku dalam penulisan unsur serapan yang baik dan benar (EYD). Sumber lain yang berkaitan dengan unsur serapan misalnya dengan membaca beberapa pustaka dan hasil penelitian.

Menurut Sugiyono metode analisis data deskriptif kualitatif dalam suatu penelitian kualitatif berguna untuk mengembangkan teori yang telah dibangun dari data yang sudah didapatkan di lapangan. Metode penelitian kualitatif pada tahap awalnya peneliti melakukan penjelajahan, kemudian dilakukan pengumpulan data, mulai observasi sampai penyusunan laporan.

Pembuatan proposal pada minggu pertama dan kedua, pelaksanaan penelitian pada minggu ketiga dan keempat, analisis data pada minggu kelima dan keenam, dan pelaporan pada minggu kesembilan dan kesepuluh

\section{HASIL PENELITIAN DAN PEMBAHASAN}

Hasil penelitian yang
dilkakukan di lapangan dengan
mengumpulkan data pengiriman
berita melalui sms oleh masyarakat,
baiki orangtua maupun mahasiswa
dan remaja yang ada di Kota Medan


sebagai lokasi penelitian ini akan diuraikan di bawah ini. Yang menjadi pokok permasalahan ini adalah Penggunaan Singkatan Kata dalam Pengiriman Berita Melalui SMS.

Penulisan Unsur Serapan

Berdasarkan taraf integrasinya unsur pnjaman dalam bahasa Indonesia dapat dibagi atas dua golongan besar. Pertama, unsur yang belum sepenuhnya terserap ke dalam bahasa Indonesia, seperti reshuffle, shuttle cock, l'exploitation de l'homme par l'homme, unsurunsur ini dipakai dalam konteks bahasa Indonesia, tetapi pengucapanya masih mengikuti cara asing. Kedua, unsur asing yang pengucapan dan penulisannya disesuaikan dengan kaidah bahasa Indonesia disuahakan agar ejaan asing hanya diubah seperlunya hingga bentuk Indonesianya masih dapat dibandingkan dengan bentuk asalnya. Di sapming itu, akhiran yang berasal dari bahasa asing diserap sebagai bagian kata yang utuh. Kaa seperti standardisasi, implementasi, dan objektif diserap secara utuh di samping kata standar, implemen, dan objek.

Berikut ini didaftarkan sebagian kata asing yang diserap ke dalam bahasa Indonesia, yang sering digunakan oleh pemakai bahasa.
Tabel 1. Kata Asing yang diserap ke dalam bahasa Indonesia

\begin{tabular}{|c|c|c|}
\hline $\begin{array}{l}\text { Kata } \\
\text { Asing }\end{array}$ & $\begin{array}{l}\text { Penyerap } \\
\text { an yang } \\
\text { Salah }\end{array}$ & $\begin{array}{l}\text { Penyerap } \\
\text { an yang } \\
\text { benar }\end{array}$ \\
\hline Risk & Resiko & Risiko \\
\hline System & Sistim & Sistem \\
\hline Effective & Efektip & Efektif \\
\hline $\begin{array}{l}\text { Techniqu } \\
\text { e. } \\
\text { Techniek }\end{array}$ & $\begin{array}{l}\text { Tehnik, } \\
\text { tehnologi }\end{array}$ & $\begin{array}{l}\text { Teknik, } \\
\text { teknologi }\end{array}$ \\
\hline Echelon & Esselon & Eselon \\
\hline Method & Metoda & Metode \\
\hline Charisma & Harisma & Karisma \\
\hline $\begin{array}{l}\text { Frequenc } \\
y\end{array}$ & Frekwensi & Frekuensi \\
\hline $\begin{array}{l}\text { Practical, } \\
\text { practisch }\end{array}$ & Praktek & Praktik \\
\hline $\begin{array}{l}\text { Percenta } \\
\text { ge }\end{array}$ & Prosentase & Presentase \\
\hline $\begin{array}{l}\text { Stratosfee } \\
r\end{array}$ & Stratosfir & Stratosfer \\
\hline $\begin{array}{l}\text { Descripti } \\
\text { on }\end{array}$ & Diskripsi & Deskripsi \\
\hline Conduite & Kondite & Konduite \\
\hline Trotoir & Trotoir & Trotoar \\
\hline Kuitante & Kwitansi & Kuitansi \\
\hline $\begin{array}{l}\text { Qualiteit, } \\
\text { quality }\end{array}$ & Kwalitas & Kualitas \\
\hline $\begin{array}{l}\text { Formeel, } \\
\text { formal }\end{array}$ & Formil & Formal \\
\hline $\begin{array}{l}\text { Rationeel } \\
\text {, rational }\end{array}$ & Rasionil & Rasional \\
\hline
\end{tabular}

Data Unsur Serapan

Berilah tanda $(\checkmark)$ pada kolom "B" jika pernyataan di bawah ini "benar" dan berilah tanda centang $(\checkmark)$ di kolom "S" jika pernyataannya "salah". 
Tabel 2. Kata Asing yang diserap ke dalam bahasa Indonesia

\begin{tabular}{|c|c|c|c|}
\hline \multirow{2}{*}{ NO } & \multirow{2}{*}{ Kalimat } & \multicolumn{2}{|c|}{ Pilihan } \\
\hline & & B & $\mathrm{S}$ \\
\hline 1 & $\begin{array}{l}\text { Seorang wirusaha } \\
\text { harus mampu } \\
\text { mengaggung } \\
\text { resiko } \\
\text { berdasarkan } \\
\text { keputusan yang } \\
\text { dia ambil }\end{array}$ & & \\
\hline 2 & $\begin{array}{l}\text { Siswa/siswi kelas } \\
\text { XII A } 1 \text { sdang } \\
\text { praktek di } \\
\text { laboratorium }\end{array}$ & & \\
\hline 3 & $\begin{array}{l}\text { Setelah diselidiki } \\
\text { ternyata masih } \\
\text { banyak guru yang } \\
\text { menilai siswanya } \\
\text { secara subjektif }\end{array}$ & & \\
\hline 4 & $\begin{array}{l}\text { Ahok merupakan } \\
\text { salah stau } \\
\text { pemimpin } \\
\text { idamanku karena } \\
\text { be3liau sangat } \\
\text { taqwa kepada- } \\
\text { Nya }\end{array}$ & & \\
\hline 5 & $\begin{array}{l}\text { Hirarki } \\
\text { oraganisme mulai } \\
\text { dari yang terkecil } \\
\text { hingga yang } \\
\text { terbesar dimulai } \\
\text { dari sel hingga } \\
\text { bioma }\end{array}$ & & \\
\hline 6 & $\begin{array}{l}\text { Hasil diganosa } \\
\text { laboratorium } \\
\text { menunjukkan } \\
\text { bahwa Andi } \\
\text { mengalami } \\
\text { amnesia pacar }\end{array}$ & & \\
\hline 7 & Saat ini Aliando & & \\
\hline
\end{tabular}

\begin{tabular}{|c|c|}
\hline & $\begin{array}{l}\text { sedang mencuci } \\
\text { rambutnya } \\
\text { menggunakan } \\
\text { shampo }\end{array}$ \\
\hline 8 & $\begin{array}{l}\text { Balon itu dijual } \\
\text { seharga dua ribu } \\
\text { rupiah per biji }\end{array}$ \\
\hline 9 & $\begin{array}{l}\text { Kemarin sore } \\
\text { tanpa disengaja } \\
\text { adik memcahkan } \\
\text { aquarium } \\
\text { kesayangan ayah }\end{array}$ \\
\hline 10 & $\begin{array}{l}\text { Saat ini Celine } \\
\text { sedang merasa } \\
\text { dilemma }\end{array}$ \\
\hline 11 & $\begin{array}{l}\text { Dari dulu saya } \\
\text { sudah katakan } \\
\text { kepadamu bahwa } \\
\text { dia aalah bandiet }\end{array}$ \\
\hline 12 & $\begin{array}{l}\text { Tanpa disengaja } \\
\text { Mann Sing } \\
\text { Khurana } \\
\text { menekan bell } \\
\text { pertanda } \\
\text { kebakaran } \\
\text { sehingga } \\
\text { membuat para } \\
\text { pegawai merasa } \\
\text { panik tak karuan }\end{array}$ \\
\hline 13 & $\begin{array}{l}\text { Kita haru } \\
\text { bersyukur apabila } \\
\text { mendapatkan } \\
\text { rezqi dari Tuhan }\end{array}$ \\
\hline 14 & $\begin{array}{l}\text { Pak Jokowi } \\
\text { memelihara } \\
\text { binatang } \\
\text { kesukaannya di } \\
\text { intana } \text { neara } \\
\text { sepser }\end{array}$ \\
\hline 15 & $\begin{array}{l}\text { Pada akhir tahun } \\
\text { barang-barang } \\
\text { yang dijula di }\end{array}$ \\
\hline
\end{tabular}




\begin{tabular}{l|l|l|l}
\hline & $\begin{array}{l}\text { toko itu kenakan } \\
\text { discount }\end{array}$ & & \\
\hline 16 & $\begin{array}{l}\text { Seorang siswa } \\
\text { dari sekoalh kita } \\
\text { mewakili seluruh } \\
\text { atleet dari } \\
\text { Indoensia }\end{array}$ & & \\
\hline 17 & $\begin{array}{l}\text { Ia meneleponku } \\
\text { dan menanyakan } \\
\text { kahabar } \\
\text { keluargaku }\end{array}$ & & \\
\hline 18 & $\begin{array}{l}\text { Dia mengganti } \\
\text { blause itu } \\
\text { menjadi warna } \\
\text { merah }\end{array}$ & & \\
\hline 19 & $\begin{array}{l}\text { Ibu Adelina } \\
\text { adalah docent } \\
\text { yang professional }\end{array}$ & & \\
\hline 20 & $\begin{array}{l}\text { Aliando adalah } \\
\text { seorang } \text { actor } \\
\text { yang sangat } \\
\text { tampan }\end{array}$ & & \\
\hline
\end{tabular}

\section{Pembahasan}

Di bawah ini akan dijelaskan proses penyerapan kosakata bahasa asing ke dalam bahasa Indonesia

a. Resiko -> berasal dari bahasa Inggris yakni "risk". Proses yang terjadi adalah penambahan bunyi di tengah kata|i| dan kata|o|" menjadi risiko

b. Praktek -> berasal dari bahaa Inggris yakni "practice". Proses yang terjadi adalah mengubah bunyi |e| menjadi bunyi k baik di tengah kata maupun di akhir kata menjadi Praktik

c. Subjektif -> bersal dari bahsa Inggris yakni "Subyektif". Proses yang terjadi adalah mengubah bunyi $|y|$ menjadi j dan mengubah bunyi $|\mathrm{e}|$ menjadi bunyi $|\mathrm{k}|$ menjadi subjektif

d. Taqwa $\rightarrow$ berasal dari bahasa Arab. Proses yang terjadi adalah mengubah bunyi $|\mathrm{q}|$ menjadi bunyi $|\mathrm{k}|$ takwa.

e. Hirarki -> berasal dari bahasa Yunani "Hierarchia". Proses yang terjadi adalah mengubah bunyi $|\mathrm{ch}|$ menjadi bunyi $|\mathrm{k}|$ dan penghilangan bunyi $|\mathrm{a}|$ di akhir kata menjadi hierarki

f. Diagnosa -> berasal dari bahasa Inggris “Diagnosis". Proses yang terjadi adalah menyerap sepenuhnya kata tersebut menjadi kosakata bahsa Indonesia yakni diagnosa

g. Shampo -> berasal dari bahasa Inggris "Shampoo". Proses yang terjadi adalah menghilangkan bunyi $|\mathrm{h}|$ di tengah kata dan penghilangan salah satu bunyi $|\mathrm{o}|$ di akhir kata menjadi sampo

h. Balon -> berasal dari bahasa Inggris yakni “Balloon”. Proses yang terjadi adalah penghilangan salah satu bunyi |1| di tengah kata dan penghilangan salah satu bunyi |o| di tengah kata menjadi Balon

i. Aquarium -> berasal dari bahasa Inggris "aquarium". Proses yang terjadi adalah mengubah bunyi $|\mathrm{q}|$ menjadi bunyi $|\mathrm{k}|$ menjadi akuarium.

j. Dilemma -> berasal dari bahasa Inggris "Dilemma". Proses yang terjadi adalah menyerap sepenuhnya kosakata bahasa Inggris ke dalam kosakata bahsa Indonesia menjadi Dilemma. 
k. Bandiet $\rightarrow$ berasal dari bahasa Inggris "bandit". Proses yang terjadi adalah menyerap sepenuhnya kosakata tersebut ke dalam kosakata bahasa Indonesia menjadi Bandit

1. Bell $\rightarrow>$ berasal dari bahasa Inggris "bell". Proses yang terjadi adalah penghilangan salah satu bunyi |1| di akhir kata menjadi Bel

m. Rezqi -> berasal dari bahasa Arab "Rizqi". Proses yang terjadi adalah mengubah bunyi |i| di tengah kata menjadi bunyi |e| dan menambah bunyi |1| sesudah bunyi $|z|$ dan mengubah bunyi $|\mathrm{q}|$ menjadi bunyi $|\mathrm{k}|$ Rezeki

n. Intana $\rightarrow$ berasal dari bahasa Saskerta "Stana". Proses yang terjadi adalah menambah bunyi |i| di awal kata menjadi istana

o. Discount -> berasal dari bahasa Inggris "Discount". Proses yang terjadi adalah mengubah bunyi |c| menjadi buyni $|\mathrm{k}|$ dan penghilangan bunyi $|\mathrm{u}|$ di tengah kata dan penghilangan bunyi $|\mathrm{t}|$ di akhir kata menjadi diskon

p. Atleet $\rightarrow$ berasal dari bahasa Inggris "Atleet". Proses yang terjadi adalah penghilangan satu bunyi |e| di tengah kata menjadi Atlet

q. Kahabar $\rightarrow$ berasal dari bahasa Arab "Khabar". Proses yang terjadi adalah menyerap keseluruhan kosakata tersebut menjadi kosakata bahasa Indonesia khabar. r. Blouse -> berasal dari bahasa Inggris "Blouse". Proses yang terjadi adalah penghilangan bunyi|o| di tengah kata dan penghilangan bunyi |e| di akhir kata menjadi blus

s. Docent $\rightarrow$ berasal dari bahasa Belanda "Dosen". Proses yang terjadi adalah menyerap sepenuhnya kosakata tersebut menjadi kosakata bahasa Indonesia menjadi Dosen.

t. Actor $\rightarrow$ berasal dari bahasa Inggris yakni Actor. Proses yang terjadi adalah mengbuah bunyi $|c|$ di tengah menjadi bunyi $|k|$ menjadi aktor

Uraian di atas dapat diketahui bahwa unsur serapan bahasa asing dapat dilakukan sebagai berikut

a. Unsur serapan bahasa asing diserap dengan sepenuhnya hal ini terjadi jika kosakata dalam bahasa Indonesia tidak mempunyai pedoman kata untuk kata tersebut

b. Unsur serapan bahasa asing sebagian yakni dengan menyesuaikan lafal ke dalam bahasa Indonesia

\section{SIMPULAN}

Berdasarkan hasil penelitian dan analisis kemampuan menulis unsur serapan oleh Mahasiswa PGSD Semester IV Kelas II, maka dapat disimpulkan sebagai berikut:

a. Kemampuan menulis suatu kegiatan komunikasi berupa penyampaian pesan (informasi) secara tertulis kepada pihak lain

b. Unsur serapan adalah kosakata yang dipinjam dari bahasa asing 
Adelina Ginting: Analisis Menulis Unsur...

$$
\begin{aligned}
& \text { dengan melalui proses yang } \\
& \text { ditetapkan oleh kaidah yang } \\
& \text { berlaku menurut Ejaan Yang } \\
& \text { Disempurnakan }
\end{aligned}
$$

c. Hasil penelitian yang dilakukan pada Mahasiswa PGSD Semester IV Kelas II Tahun Pelajaran 2015-2016 kurang memuaskan, karena ternyata $48,27 \% \quad(14$ orang) mahasiswa tergolong kategori baik, 24,13\% (7 orang) mahasiswa tergolong kateogri cukup, dan $27,58 \%$ (8 orang) mahasiswa tergolong kategori kurang baik.

d. Kebanyakan penulisan unsur serapan yang salah dipilih oleh mahasiswa adalah unsur serapan yang selalu dipergunakan dalam kehidupan sehari-hari.

\section{DAFTAR RUJUKAN}

Alex \& Ahmad, 2011. Bahasa Indonesia Untuk Perguruan Tinggi. Jakarta: Kencana Perdana Media Group.

Arikunto. 1991. Prosedur Penelitian.

Jakarta: Rineka Cipta.

Chaer, Abdul. 1998. Tata Bahasa Praktis Bahasa Indonesia. Jakarta: Rineka Cipta.

Hartanto, S. 1995. Pedoman Umum Pembentukan Istilah Dan Pedoman Umum Ejaan Bahasa Indonesia Yang

Disempurnakan (EYD).

Surabaya: Penerbit INDAH Surabaya.
Moeliono, M. Anton dkk. 1998. Tata Bahasa Baku Bahasa Indonesia. Jakarta: Balai Pustaka.

Nababan, Diana. 2008. Intisari Bahasa Indonesia Untuk SMA. Jakarta: Kawan Pustaka.

Sugiyono. 2012. Metode Penelitian Kualitatif dan $R \& D$. Bandung: Alfabeta.

Sutopo, H.B. 2002. Metode Penelitian Kualitatif; Dasar Teori dan Penerapannya dalam Penelitiani. Surakarta: UNS Press.

Saddhono, Kundharu dan Y. Slamet. 2014. Pembelajaran dan Keterampilan Berbahasa Indonesia. Yogyakarta: Graha Ilmu.

Tantawi, Isma. 2015. Bahasa Indonesia Akademik. Bandung: Citapustaka Media.

Tarigan, Henry Guntur. 1993. Menulis Sebagai Suatu Keterampilan Berbahasa. Bandung: Angkasa Bandung. 